\title{
WHO WILL BEAT THE CRISIS? SEARCHING FOR FACTORS THAT DEFINE SUCCESSFUL COPING WITH JOB LOSS AMONG WORKING PEOPLE IN CROATIA
}

\author{
Darja Maslić Seršić \\ University of Zagreb, Croatia \\ E-mail: darja.maslic@ffzg.hr \\ Majda Šavor \\ Croatian Employment Service, Croatia \\ E-mail: msavor@inet.hr
}

\begin{abstract}
The study deals with individual factors that are related to more or less adaptive behavior in the situation of job loss. Problem-and emotion-oriented coping strategies, their antecedents and consequences were in the focus. The data were obtained through a two-wave longitudinal study on a sample of 462 persons of various demographic and work characteristics who had recently lost their jobs. In the first wave, data on their demographic and work characteristics, experienced resources (financial situation, core self-evaluation, social support, job involvement and job-search self-efficacy) and strategies of proactive job search, occasional work, job-loss distancing and job devaluation were collected. In a follow-up study, conducted after six months, employment status and perceived work uncertainty were in the focus. The results can be summarized in several general findings: (1) Different patterns of individual characteristics were related to the tendency to use the individual strategy more or less intensively, and the strategies showed different adaptive roles in terms of their relations to measured outcomes; (2) The availability of coping resources is a significant predictor of the most adaptive, problem-oriented, strategy of proactive job search; (3) Some measured resources were not related to emotion-oriented strategies, and some of them stood in negative relations; (4) Proactive job search, but not the measured resources, was a significant independent predictor of reemployment six months later, in addition to age and education level; (5) Employment status, measured after six months, was a significant independent predictor of the concurrent experience of work uncertainty - reemployed individuals experienced less anxiety regarding their future work; (6) Demographic variables and measured resources served alongside current employment status as significant predictors of work uncertainty, but strategies did not.
\end{abstract}

Key words: coping resources, coping strategies, job loss, unemployment, work uncertainty.

\section{Introduction}

As other social transitions have done in the past, the current economic crisis is producing social changes that can have significant long-term impact on individual work behavior (e.g., Calhoun, 1992; Elder, 1974; Silbereisen, Pinquart, \& Tomasik, 2010). Increased instability in the business sector, and its manifestations in permanent organizational restructuring and downsizing, have changed people's perception of employment as the most important source of security and financial well-being. Many individuals have been forced into discontinuous career transitions, often followed by periods 
of unemployment. In response to these circumstances, people rethink their own career identity and change the values and norms that determine future career behavior (e.g., Arnold \& Cohen, 2008; Fugate, Kinicki, \& Ashforth, 2004; Savickas, 2005). In the process, many personal and situational factors impact the individual pattern of change, as well as a general trend of this change in terms of enhancement or aggravation of individual well-being and work efficacy (e.g. Kanfer, Wanberg, \& Kantrowitz, 2001, Van Dam \& Menting, 2012; Vansteenkiste at al., 2004). At both individual and social levels we can recognize "the winners and losers of the change" (Obschonka, Silbereisen, \& Wasilewski, 2012, p.12), and their presence gives rise to the question of what factors could predict these different outcomes.

However, most research has confirmed that current global socio-economic changes have produced an increased uncertainty that has generally negative impact on individual well-being (e.g., De Witte, 1999; Dekker \& Schaufeli, 1995; Leana \& Feldman, 1992; Kalleberg, 2009; Mantler et al., 2005; Sverke \& Hellgren, 2002). Besides, there are sound proofs of the stressfulness of job loss, as well as a negative association between unemployment and well-being. In meta-analytic studies, McKee-Ryan et al., (2005) showed that unemployment is related to psychosomatic symptoms and anxiety, depression and a lower level of life satisfaction and self-esteem, and Paul and Moser (2009) found a profoundly higher rate of reported psychological problems among the unemployed than among those in employment. Zenger et al. (2011) recently found that the experience of repeated periods of unemployment during working life has long-term effects and is connected to poorer psychological well-being among retired individuals. As mentioned above, these relations between job insecurity and unemployment, and deterioration in well-being, are not always simple and straightforward.

Regarding individual differences in the consequences of job loss or involuntary discontinuous career transitions, it is reasonable to focus on individual coping strategies, as well as the factors that may impact their manifestations and long-term outcomes. Therefore, considerable effort has been put into defining the causes and manifestations of job-search behavior. Kanfer, Wanberg, \& Kantrowitz (2001) defined this strategy as a purposive, volitional and self-managed pattern of action with the goal of achieving reemployment, and they showed, through a meta-analytic study, that job search is a significant predictor of reemployment. This adaptive problem-oriented strategy is also seen as an important individual competence in a time of intensified work uncertainty. However, the efficacy of job search depends on situational and individual factors, and especially fades in a time of crisis, when job seekers highly outnumber job openings. In a recent Croatian study it was found that jobseeking intensity was not a significant predictor of the reemployment of unemployed persons after 15 months, and was a small-sized predictor of reemployment after 27 months. Individual demographic characteristics and coping resources had greater impact on the prediction ( verko et al., 2008a). Song, Wanberg, Niu, and Yizhong (2006) found a negative relationship between job-search intensity and reemployment speed among unemployed persons in China. Finally, while studying the sense of selfcontinuity as a resource for adaptive coping with job loss, Sadeh and Karniol (2012) recently noted that "to the extent that the situation that is the cause of the distress cannot be controlled, problemfocused coping can be harmful, rather than beneficial..." (p. 2).

Certainly, job search is not the only possible and inherent strategy of coping with job loss. People use a complex combination of problem-oriented and emotion-oriented strategies of coping with stressful events (Lazarus \& Folkman, 1984). The prevalence of problem-oriented and emotion-oriented coping strategies, as well as their effectiveness, depends on the stressful event per se and the time that has passed since that event, as well as on broader circumstances such as culture. Furthermore, coping strategies are not the only factor that predicts outcomes of involuntary job loss. As mentioned before, they are not often the most important factor, and other work-related characteristics of a person play relevant roles in her successful adaptation to forced work transitions. With that in mind, this study focused on individual emotion- and problem-oriented strategies of coping with involuntary job loss, their antecedents and outcomes. The general goal was to upgrade our knowledge on the individual factors that are related to more and less adaptive behavior in a situation of job loss. We defined successful coping in terms of reemployment and less anxiety regarding work uncertainty, and grounded our research in the general context of Lazarus and Folkman's (1984) stress theory and the model of employability proposed by Fugate, Kinicki, and Ashforth (2004; see also Fugate \& Kinicki, 2008). 
The variables of interest were: financial situation (Gowan \& Gatewood, 1997; Ullah, 1990), core self-evaluations (Wanberg et al., 2005), social support (Creed \& Moore, 2006; Feather \& O'Brien, 1987; Wanberg, Watt, \& Rumsey, 1996), job involvement (Lai \& Chan, 2002; Prussia, Fugate, \& Kinicki, 2001; Vinokur \& Caplan, 1987; Wanberg, Kanfer, \& Rotundo, 1999) and job-search selfefficacy (Rife \& Kilty, 1990; Wanberg, Kanfer, \& Rotundo, 1999; Wanberg et al., 2005). Several demographic characteristics were also in the focus: in addition to age and gender, we measured two additional individual characteristics that could impact employability - level of education and organizational tenure in last employment. Level of education was a measure of human capital, and organizational tenure in last employment indicated individual work flexibility (Fugate, Kinicki, \& Asforth, 2004). We treated these variables as the individual coping capacities that mediate the relationship between the event of job loss and the individual coping strategies (Kinicki \& Latack, 1990) but could also directly impact reemployment after job loss. According to the specific models of coping with job loss, we supposed that the measured resources could serve as predictors of different coping strategies (e.g., Latack, 1986; Kinicki \& Latack, 1990; Leana \& Feldman, 1995). In that instance, the current study was explorative and focused on describing the individual predictors of specific coping strategies that have prevalence among working people in Croatia: proactive job search, occasional work, distancing and job devaluation (Maslić Seršić \& Šavor, 2011).

The relations between the measured variables and future outcomes in terms of reemployment and work anxiety were in the focus of the follow-up study. Three specific hypotheses were tested: (H1) It is supposed that future employment status will be related to perceived work uncertainty: Successful-that is, reemployed - individuals will experience less anxiety regarding their future work status than individuals who are still unemployed six months after job loss. Moreover, a general hypothesis on the significant and independent impact of the coping strategies in the prediction of reemployment and well-being after job loss was tested. Two specific hypotheses regarding the adaptive function of the measured strategies were tested: (H2) The active problem-oriented strategy of job search will be a significant predictor of reemployment after six months, in addition to the coping resources and demographic characteristics of an individual, and that will not be the case with the other active problem-oriented strategy, that of occasional work. (H3) The emotion-oriented strategies of problem distancing and job devaluation will be significant independent predictors of work-related anxiety six months later, in addition to the current employment status, coping resources and demographic characteristics of the individual. People who show a tendency for using these emotion-oriented strategies after job loss will report less anxiety regarding their future work status after six months.

\section{Methodology of Research}

A follow-up study with two waves of data-collecting was conducted. The first data collection focused on the predictors of the individual strategies of coping with job loss. For that purpose, demographic characteristics of the participants, as well as the factors that were defined as the individual and situational coping resources, were measured in addition to the coping strategies. The second data collection, conducted after six months, was focused on the consequences of the specific strategies in terms of reemployment and perceived work uncertainty.

\section{Participants and Procedure}

A convenient sample of 462 newly unemployed persons of various demographic and work characteristics represented the research participants. As the population of registered unemployed persons in Croatia is characterized by a large number of long-term unemployed individuals $-60 \%$ for longer than a year and over one third for more than three years (HZZ, 2010) - new unemployment was defined as lasting no more than a year. The sample also did not involve people who had been unemployed for less than one month, because of the time needed for the manifestation of coping strategies. In sum, our participants had been unemployed for between 1 and 12 months $(\mathrm{M}=4.9$; $\mathrm{SD}=3.64)$ and all of them had previously had full-time employment. $263(56.9 \%)$ of the sample were women, and the ages of the participants ranged from 18 to 61 years $(\mathrm{M}=36.1$; $\mathrm{SD}=11.33)$. The organizational tenure in their last employment ranged from 2 weeks to 31 years (in months, 
$\mathrm{M}=33.4 ; \mathrm{SD}=64.2$ ). $10.2 \%$ of participants had elementary school education or less (up to $8 \mathrm{yrs}$ ), $55.7 \%$ had completed some vocational or high school (10-12 yrs of education) and $26.8 \%$ had college or university education (14 yrs or more). 173 (37.4\%) had been laid off after downsizing or organizational restructuring, and $289(62.5 \%)$ had lost employment after the expiration of a fixedterm contract, or quit their employment for some other reason.

The first data collection was organized as field work conducted in the regional branch office of the Croatian Employment Service in Zagreb. The interviewers - 12 trained senior students of psychology - approached all the people who came to the office to make their obligatory monthly report and asked them to participate in a follow-up study on coping with job loss. Before that, they asked them the duration of their unemployment and their previous work status, to exclude the long-term unemployed and those who had never been employed. The participants completed the questionnaire in an individualized procedure in a separate room. The methodology of group guided survey application was used. After receiving initial instructions and guidance, most of the respondents completed the questionnaire by themselves. The interviewers helped a small number of respondents who had difficulties in reading and writing, by reading questions and filling in their answers.

Participants usually completed the questionnaire in 20 minutes, and for this participation were paid 30 Kunas (ca 4 Euros). At the end, 341 participants (84.6\%) agreed to write their names and phone-contact details on a separate sheet of paper. The interviewers explained to them that the study was anonymous and that personal data (name and contact details given on the separate sheet of paper) would serve for the follow-up, and would not be connected to the data given in the questionnaires. Participants were informed that they would be contacted by phone in six months to check their employment status and collect data on current feelings and behaviors.

The second data collection was organized by phone. The same senior students served as interviewers, and data collection lasted around 5 minutes. Dropout was not high - $62(18 \%)$ participants were not available, and 13 (4\%) refused to participate. Consequently, 274 participants participated in the second wave of data collection. Their demographic characteristics were comparable to the initial sample.

\section{Measures}

Three categories of variables were measured in the field study: demographic and work characteristics, individual coping resources and coping strategies. Employment status and subjective work certainty were measured in the follow-up.

Demographic and work characteristics were measured by a standard 1-item measure related to gender, age, education level (1 - no school, to 8 - Ph.D.) and organizational tenure in last employment.

Individual coping resources were defined as financial status, core self-evaluation, social support, job involvement and job-search efficacy. All variables were measured as self-rated. Financial status was measured as subjective financial strain covered by questions about frequency of general and specific (regarding housing, food, bills, medicines, etc.) financial worries, expressed on scales from 1 to 4 (1- no worries at all; 4 - a great number of worries) (Galić, Maslić Seršić, \& Šverko, 2006; Šverko, Galešić, \& Maslić Seršić, 2004). Factor analysis showed that all items loaded highly on one factor, so we averaged the items in one composite variable ( 8 items, $\alpha=0.92)$. Core self-evaluation was defined as a general concept that involves the constructs of self-esteem, locus of control, generalized self-effectiveness and emotional stability, and was measured by a scale constructed by Judge et al. (2003). Respondents indicate their answers on a 5-point Likert scale. The scale showed expected and good metric characteristics in the current study ( 12 items, $\alpha=0.86$ ). We used summed scores as a composite measure of core self-evaluation. Social support was measured by a scale adapted from Abbey, Abramis, and Caplan (1985) including items asking about the degree to which respondents' significant others provided them with "encouragement", "useful information" and "direct help". The response scale was from 1, indicating minimum support, to 4 , indicating maximum support, and we used summed scores as a composite measure of experienced accessibility of social support ( 8 items, $\alpha=0.91)$. Job involvement was defined through a work valuation scale adapted from Warr, Cook, and Wall (1979), with typical items (evaluated on a 4-point scale) such as "Having a job is 
very important for me" and "Even if I won a great deal of money in the lottery, I would accept a job". A composite variable was formed by averaging the results for each item ( 6 items, $\alpha=0.76)$. of 6 questions on individual competences necessary for successful job search: ability in application and CV writing, self-presentation skills, professional skills and knowledge, and availability of information on potential employment. Respondents have to indicate self-ratings as to the level to which they believe they have the described competences. A 5-point scale was used (1 - not able to do that at all; 5 - completely sure of one's own ability to do that successfully), and a composite measure was used as an indicator of the individual self-perceived job-search efficacy ( 6 items, $\alpha$ $=0.80)$.

Coping strategies was measured by a 26 -item questionnaire that defined two active, problemoriented strategies - proactive job search ( 7 items, $\alpha=0.88$; a typical item is "I send applications to open jobs"), occasional (declared or undeclared) work (6 items, $\alpha=0.81$; a typical item is "I try to find occasions for earning some cash") - and two passive, emotion-oriented strategies: problem distancing ( 6 items, $\alpha=0.64$; a typical item is: "I am trying to find ways to calm down"), downplaying the importance of employment ( 7 items, $\alpha=0.69$; typical item: "Like anything else, even unemployment has some advantages"). On a 4-point scale, respondents had to indicate how often they used a certain coping strategy ( 1 - never; 4 - often), and we calculated the average rating for each strategy. The questionnaire had been constructed in our previous study (Maslić Seršić \& Šavor, 2011). In the process, our starting point was the 17-item questionnaire constructed by Latack and Kinicki (1990), several Croatian studies on Lazarus's stress theory (Arambašić, 1994; Buško, 1995; Vukelić, 2003) and qualitative data obtained during regular counseling work with unemployed people.

Employment status, in the second wave of data-collecting, was covered by an item on having declared employment with a full or fixed-term working contract.

Subjective work uncertainty was measured by an item on perceived worry about future work status, which was applied to those still unemployed, as well as reemployed participants. On a 5-point scale they estimated answers to the question "How much are you concerned about your employment status in the future?"

\section{Data Analysis}

The relations between examined demographic and work characteristics, as well as individual coping resources, and the individual coping strategies were analyzed through four linear hierarchical regression analyses, conducted in two steps. Measured coping strategies served as the criterion variable. Logistic regression analysis was used when the contribution of problem-oriented coping strategies to the prediction of reemployment was tested (Hypothesis 2). Again, linear hierarchical regression analysis was used to test the contributions of employment status (Hypothesis 1) and emotion-oriented strategies (Hypothesis 3) to the prediction of subjective work uncertainty.

\section{Results of Research}

\section{Bivariate Correlations between Searched Variables}

Table 1 lists the arithmetic means, standard deviations and Pearson bivariate correlations between searched variables. Most correlations are small $(<0.20)$ or insignificant, and the highest correlations were measured between age and organizational tenure in last employment $(\mathrm{r}=0.44)$, core self-evaluation and the emotion-oriented coping strategy of problem distancing $(\mathrm{r}=-0.41)$ and between job involvement and the problem-oriented strategy of proactive job search $(\mathrm{r}=0.49)$. Among the variables that served as predictors in the subsequent regression analyses, where coping strategies served as criterion variables, only age and gender did not correlate significantly with proactive job search. More educated participants, and those who had less previous organizational tenure, indicated a higher level of this control-oriented coping strategy. The correlations were low, 
amounting to 0.11 and -0.17 , respectively. Individual resources also correlated significantly with job search, and to a rather higher degree (correlations ranged between 0.13 and 0.49 ). A different pattern of correlations was obtained for the second control-oriented strategy-occasional work. This strategy did not correlate significantly with core self-evaluation and social support, and correlations with other resources were positive and ranged between 0.14 and 0.21. All measured biographic variables, except age, correlated significantly with this strategy (values ranged between -0.10 and -0.22 ). Men, less educated individuals and those of less organizational tenure in the last job used the strategy of occasional work more intensively.

The emotion-oriented strategy of problem distancing was observed in a higher level among older and less educated individuals (with correlations of -0.20 and -0.23 , respectively). This strategy did not correlate significantly with job involvement and social support. Its correlations with core self-evaluation and job-search efficacy were negative (at -0.41 and -0.15 , respectively) and the correlation with perceived financial deprivation was positive $(\mathrm{r}=0.21)$. Finally, job devaluation did not correlate with biographic variables. This is the only strategy that correlated negatively with subjective financial deprivation $(\mathrm{r}=-0.21)$ and job involvement $(\mathrm{r}=-0.27)$. The correlations with other coping resources were also significant, but positive, and ranged between 0.14 and 0.27 .

The problem-oriented coping strategies of job search and occasional work were in a significant positive correlation $(\mathrm{r}=0.37)$, as well as the two emotion-oriented strategies $(\mathrm{r}=0.11 ; \mathrm{p}<0.05)$. Job search was linked negatively to distancing $(\mathrm{r}=-0.19)$ and positively to occasional work $(\mathrm{r}=0.11$; $\mathrm{p}<0.05)$.

Perceived work uncertainty, the variable measured in the follow-up study six months later, showed significant and positive correlations with age, organizational tenure in last employment, perceived financial deprivation, job involvement and the strategy of problem distancing. (Coefficients ranged between 0.12 and 0.27$)$. Significant negative correlations were obtained for education $(\mathrm{r}=$ -0.14 ) and core self-evaluation $(\mathrm{r}=-0.21)$. Subsequent employment status correlated significantly with biographic variables, but not with measured resources. Younger, more educated participants and those with less organizational tenure in their last job were more often reemployed after six months. Job search correlated positively with subsequent reemployment, and with distancing negatively. Distancing was also in a significant and positive correlation with work uncertainty $(\mathrm{r}=0.27)$, which significantly correlated with employment status. Reemployed individuals perceived significantly lower levels of work uncertainty than individuals who were still unemployed $(\mathrm{r}=-0.29)$.

Table 1. Arithmetic means, standard deviations and Pearson's bivariate correlations between searched variables $(\mathrm{N}=462)$

\begin{tabular}{|c|c|c|c|c|c|c|c|c|c|c|c|c|c|c|c|}
\hline VARIABLE & 1 & 2 & 3 & 4 & 5 & 6 & 7 & 8 & 9 & 10 & 11 & 12 & 13 & 14 & 15 \\
\hline 1. Gender & 1 & & & & & & & & & & & & & & \\
\hline 2. Age & .011 & 1 & & & & & & & & & & & & & \\
\hline 3. Education & $.136^{* *}$ & .035 & 1 & & & & & & & & & & & & \\
\hline $\begin{array}{l}\text { 4. Org. ten. } \\
\text { in last } \\
\text { employment }\end{array}$ & $.102^{*}$ & $.435^{* *}$ & .072 & 1 & & & & & & & & & & & \\
\hline $\begin{array}{l}\text { 5. Perceived } \\
\text { finan. } \\
\text { Deprivation }\end{array}$ & .052 & $.339^{* *}$ & $-.169^{* *}$ & .001 & 1 & & & & & & & & & & \\
\hline $\begin{array}{l}\text { 6. Core self- } \\
\text { evaluation }\end{array}$ & $-.098^{*}$ & $-.177^{\star *}$ & .014 & .073 & $-.316^{* *}$ & 1 & & & & & & & & & \\
\hline $\begin{array}{l}\text { 7. Social } \\
\text { support }\end{array}$ & $.112^{*}$ & $-.201^{* *}$ & -.040 & -.011 & $-.316^{* *}$ & $.264^{* *}$ & 1 & & & & & & & & \\
\hline $\begin{array}{l}\text { 8. Job search } \\
\text { efficacy }\end{array}$ & -.023 & $-.113^{*}$ & .027 & $-.105^{*}$ & $-.121^{*}$ & $.340^{* *}$ & $.301^{* *}$ & 1 & & & & & & & \\
\hline $\begin{array}{l}\text { 9. Job } \\
\text { involvement }\end{array}$ & $.107^{*}$ & .054 & .010 & $-.124^{\star \star}$ & $.216^{* *}$ & $-.132^{\star *}$ & .071 & $.200^{* *}$ & 1 & & & & & & \\
\hline
\end{tabular}




\begin{tabular}{|c|c|c|c|c|c|c|c|c|c|c|c|c|c|c|c|}
\hline VARIABLE & 1 & 2 & 3 & 4 & 5 & 6 & 7 & 8 & 9 & 10 & 11 & 12 & 13 & 14 & 15 \\
\hline $\begin{array}{l}\text { 10.Proactive job } \\
\text { search }\end{array}$ & .031 & . 028 & $.108^{*}$ & $-.169^{* *}$ & $.186^{* *}$ & $.127^{* *}$ & $.174^{* *}$ & $.374^{* *}$ & $.485^{* *}$ & 1 & & & & & \\
\hline $\begin{array}{l}\text { 11. Occasional } \\
\text { work }\end{array}$ & $-.172^{\star *}$ & -.037 & $-.095^{\star}$ & $-.224^{* *}$ & $.212^{* *}$ & -.016 & -.047 & $.137^{* *}$ & $.206^{* *}$ & $.365^{* *}$ & 1 & & & & \\
\hline 12.Distancing & .074 & $.196^{* *}$ & $-.232^{* *}$ & * .005 & $.210^{\star *}$ & $-.411^{* *}$ & -.046 & $-.148^{* *}$ & .040 & $-188^{* *}$ & $.106^{*}$ & 1 & & & \\
\hline $\begin{array}{l}\text { 13.Job } \\
\text { devaluation }\end{array}$ & .024 & -.059 & .025 & .063 & $-.211^{* *}$ & $.272^{* *}$ & .140 & $.129^{* *}$ & $-.257^{\star \star}$ & -.018 & .062 & $.110^{*}$ & 1 & & \\
\hline $\begin{array}{l}\text { 14.Subj. work } \\
\text { uncertaintya }\end{array}$ & .097 & $.267^{* *}$ & $-.141^{*}$ & $.146^{*}$ & $.203^{* *}$ & $-.207^{* *}$ & .051 & -.109 & $.123^{*}$ & .055 & -.007 & $.271^{* \star}$ & -0.67 & 1 & \\
\hline $\begin{array}{l}\text { 15.Employment } \\
\text { statusa }\end{array}$ & -.016 & $-257^{\star \star}$ & $.147^{*}$ & $-.138^{*}$ & .106 & .038 & -.093 & -.055 & -.078 & $.212^{* *}$ & .077 & $-.218^{\star \star}$ & -.081 & $-293^{\star *}$ & 1 \\
\hline M & - & - & - & - & 2.78 & 3.19 & 3.00 & 3.87 & 3.28 & 3.41 & 2.62 & 2.32 & 2.77 & 3.12 & - \\
\hline$S D$ & - & - & - & - & .741 & .498 & .712 & .653 & .557 & .617 & .777 & .605 & .585 & 1.225 & - \\
\hline Cronbach $\alpha$ & - & - & - & - & .92 & .73 & .91 & .80 & .76 & .88 & .81 & .64 & .69 & & - \\
\hline
\end{tabular}

Volume 2, 2012

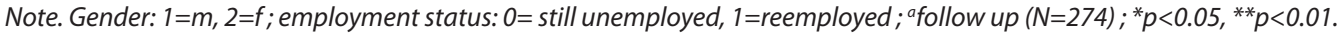

\section{Biographic Variables and Coping Resources as Predictors of Individual Coping Strategies}

To find out whether demographic characteristics, as well as individual coping resources, predict the measured coping strategies, four linear multiple regression analyses were performed in two steps. The measured coping strategies (proactive job search, occasional work, problem distancing and job devaluation) served as the criterion variables. Gender, age, education level and organizational tenure in last employment were entered each time in the first step, and financial status, core self-evaluation, social support, job involvement and job-search efficacy in the second step, of each analysis. Table 2 summarizes the results of the four multiple regression analyses: the cumulative ( $R$, adjusted $\mathrm{R}^{2}$, $\Delta \mathrm{R}^{2}$ ) and independent (standardized $\beta$ coefficients) contribution of examined biographic and resource variables to the explanation of individual coping strategies.

When job-search behavior served as the criterion, $35 \%$ of the total variance was explained. Biographic variables, when entered in the first step, explained $3 \%$ of the individual differences in job-search intensity. Age, level of education and organizational tenure in last employment were significant predictors. In the second step of the analysis, the impact of age became insignificant, obviously mediated by measured resources that were all significant predictors of this strategy, with the exception of social support.

$15 \%$ of the total variance (with an approximately equal contribution from both steps) was explained when the other control-oriented strategy, occasional work, served as the criterion. This strategy is more common among male unemployed persons and those who have had shorter organizational tenure before becoming unemployed, and these biographic characteristics were not mediated by coping resources. Among measured resources, subjective financial deprivation, job involvement and job-search efficacy were independent significant predictors of occasional work. Core self-evaluation and social support were not significant resources for this strategy.

Searched predictors explained, in total, $23 \%$ of individual differences in problem distancing. Biographic variables explained $10 \%$ of the total variance and all measured variables, and only organizational tenure in last job was not a significant predictor in the first step of the analysis. Among coping resources, core self-evaluation and social support were significant independent predictors of this strategy. They also mediated the significant impact that gender and organizational tenure in last job had in the first step. According to the significant predictors in the second step, we can conclude that the older and less educated individuals, and those with lower core self-evaluation, but with more social support, use this emotion-oriented strategy more intensively while dealing with job loss.

Only the second step made a significant contribution to the prediction of the other emotionoriented strategy - job devaluation. $10 \%$ of the total variance was explained, and job involvement and core self-evaluation were significant independent predictors. Individuals who indicated a higher 
level of core self-evaluation and a lower level of job involvement showed a tendency toward using this emotion-oriented strategy.

Table 2. The role of biographic characteristics and individual coping resources in predicting individual coping strategies with job loss: Results of linear regression analyses $(\mathrm{N}=462)$.

\begin{tabular}{|c|c|c|c|c|c|c|c|c|}
\hline & \multicolumn{2}{|c|}{ Job Search } & \multicolumn{2}{|c|}{ Occasional Work } & \multicolumn{2}{|c|}{ Distancing } & \multicolumn{2}{|c|}{ Job Devaluation } \\
\hline & 1. step & 2. step & 1. step & 2. step & 1. step & 2. step & 1. step & 2. step \\
\hline & $\beta$ & $\beta$ & $\beta$ & $\beta$ & $\beta$ & B & $\beta$ & $\beta$ \\
\hline \multicolumn{9}{|l|}{ Biographic variables } \\
\hline Gender & .062 & -.006 & $-.169^{\star *}$ & $-.185^{\star *}$ & $.122^{*}$ & .059 & .020 & .066 \\
\hline Age & $.147^{*}$ & .072 & .079 & -.030 & $.264^{* *}$ & $.203^{* *}$ & -.095 & .023 \\
\hline Education & $.119^{*}$ & $.179^{\star \star}$ & -.051 & -.012 & $-.224^{\star *}$ & $-.201^{* *}$ & .016 & -.002 \\
\hline $\begin{array}{l}\text { Org.tenure at last } \\
\text { employment }\end{array}$ & $-.177^{* *}$ & $-.115^{*}$ & $-.235^{\star *}$ & $-.164^{* *}$ & $-.133^{*}$ & -.077 & $.116^{*}$ & .034 \\
\hline \multicolumn{9}{|l|}{ Coping resources } \\
\hline $\begin{array}{l}\text { Percived financial } \\
\text { deprivation }\end{array}$ & & $.234^{* *}$ & & $.223^{* *}$ & & .027 & & .080 \\
\hline Core self-evaluation & & $.166^{* *}$ & & .015 & & $-.377^{* *}$ & & $.170^{* *}$ \\
\hline Social support & & .077 & & -.034 & & $.155^{* *}$ & & .036 \\
\hline Job search efficacy & & $.220^{* *}$ & & $.135^{\star}$ & & -.040 & & .071 \\
\hline Job involvement & & $.375^{\star *}$ & & $.127^{\star}$ & & -.053 & & $-.199^{* *}$ \\
\hline $\mathbf{R}$ & $.209^{* *}$ & $.602^{* *}$ & $.297^{* *}$ & $.416^{* *}$ & $.335^{* *}$ & $.501^{* *}$ & .119 & $.343^{* *}$ \\
\hline Adjusted R2 & $.033^{* *}$ & $.346^{\star \star}$ & $.079^{\star *}$ & $.153^{* *}$ & $.103^{\star *}$ & $.233^{* *}$ & .004 & $.096^{\star *}$ \\
\hline$\Delta R 2$ & $.044^{* *}$ & $.318^{\star *}$ & $.088^{* *}$ & $.085^{* *}$ & $.112^{* *}$ & $.139^{* *}$ & .014 & $.104^{* *}$ \\
\hline
\end{tabular}

Note. Gender: $1=m, 2=f ;{ }^{*} p<0.05,{ }^{* *} p<0.01$

\section{The Follow-up Study: Predictors of Reemployment and Perceived Work Uncertainty}

To test the relations between searched variables and reemployment after six months, logistic regression analysis was performed. In the second wave of data collection, employment status served as a bivariate criterion variable, and demographic and work characteristics (gender, age, education level and organizational tenure in last employment), coping resources (financial status, core selfevaluation, social support, job involvement and job-search efficacy) and coping strategies (proactive job search, occasional work, problem distancing and job devaluation) served as predictors. Three models were tested: the first with the measured biographic variables serving as predictors, a second in which coping resources were added to the equation, and a third with coping strategies in the equation.

In the first model, we tested the contribution of the individual biographic characteristics to the prediction of employment status. The model was significant $\left(\chi^{2}=27.30 ; \mathrm{df}=4 ; \mathrm{p}<0.01\right)$, and two biographic characteristics (age and level of education) had significant $B$ coefficients at $p<0.01$ (counting -0.05 and 0.32 , respectively). Younger and more educated persons were more often reemployed after six months. On the basis of the measured biographic variables, $60.3 \%$ of correct classifications regarding subsequent employment status were reached. The measured coping resources did not have 
a significant impact on the prediction $\left(\chi^{2}=2.66 ; \mathrm{df}=5 ; \mathrm{p}>0.05\right)$. The first model of prediction was not significantly improved by adding coping resources, and age and level of education remained the only independent significant predictors of employment status measured in the follow-up. Individual coping strategies, when added to the biographic variables, significantly improved the prediction $\left(\chi^{2}\right.$ $=18.94 ; \mathrm{df}=4 ; \mathrm{p}<0.01)$, and proactive job search was the only strategy with a significant $\mathrm{B}$ coefficient. The total model, comprising measured biographic variables and coping strategies as predictors, provided $66.4 \%$ of correct classifications regarding employment status in the follow-up $\left(\chi^{2}=\right.$ 46.24; $\mathrm{df}=8 ; \mathrm{p}<0.01)$. Age $(\mathrm{B}=-0.06 ; \mathrm{p}<0.01)$, level of education $(\mathrm{B}=0.29 ; \mathrm{p}<0.05)$ and the strategy of proactive job search $(\mathrm{B}=0.83 ; \mathrm{p}<0.01)$ were independent significant predictors.

Linear hierarchical regression analysis was performed with subjective work uncertainty serving as the criterion. In this case, employment status was entered as a dummy variable (0 - still unemployed; 1 - reemployed) in the first step of the analysis, together with biographic variables (gender, age and organizational tenure in last employment). Coping resources were entered in the second, and coping strategies in the third, step of the analysis.

The entered predictors explained $19.5 \%$ of individual differences in the concern indicated regarding work certainty $\left(\mathrm{R}=0.486 ; \mathrm{p}<0.01\right.$; adj. $\left.\mathrm{R}^{2}=19.5\right)$. The first step of the analysis, comprising biographic variables, explained more than $13 \%$ of the total variance $(\mathrm{R}=0.387 ; \mathrm{p}<0.01$; adj. $\left.R^{2}=13.4\right)$, and three variables had significant $\beta$ coefficients: employment status $(\beta=-0.218 ; p<0.01)$, age $(\beta=0.105 ; p<0.01)$ and level of education $(\beta=-0.125 ; p<0.05)$. Coping resources, when entered in the second step, significantly added to the prediction $\left(R=0.468 ; \mathrm{p}<0.01 ;\right.$ adj. $\mathrm{R}^{2}=0.189 ; \Delta \mathrm{R}^{2}=0.07$; $\mathrm{F}=4.695 ; \mathrm{df}=5 ; \mathrm{p}<0.01)$ and mediated the significant impact that level of education had in the first step. Both employment status and age kept significant $\beta$ coefficients in the second step, and two individual coping resources - core self-evaluation $(\beta=-0.158 ; p=0.01)$ and social support $(\beta=0.193$; $\mathrm{p}<0.01)$ were significant independent predictors, too. Individual coping strategies, when entered in the third step, did not significantly add to the prediction $\left(\Delta \mathrm{R}^{2}=0.017 ; \mathrm{F}=1.418 ; \mathrm{df}=4 ; \mathrm{p}=0.228\right)$. Younger and reemployed individuals, as well as those who had experienced higher core self-evaluation and more social support after job loss reported less anxiety regarding future employment status in the follow-up.

\section{Discussion}

In stressful circumstances, people usually express a complex pattern of different strategies. Behavioral arts that Croatian people express while dealing with job loss can be reduced to four general coping strategies: the problem-oriented strategies of proactive job search and occasional work, and the emotion-oriented strategies of problem distancing and employment devaluation (Maslić Seršić \& Šavor, 2011). While job search is a universal problem-oriented strategy, traditionally treated as an adaptive behavior that leads to the desirable outcome of reemployment (Leana \& Feldman, 1990; Leana, Feldman, \& Tan, 1998; Wanberg et al., 2005), the strategy of occasional work is specific. It is related to the gray economy, the phenomenon of undeclared work, which has different prevalence in different countries, and its highest levels can be found in the transitional New Member States (Pederson, 2003; Renoy et al., 2004). In a recent Croatian study, Šverko et al. (2008) found that more than $40 \%$ of the registered unemployed population in Croatia is engaged in some undeclared work. Therefore, it is not surprising that occasional work is an inherent strategy of coping with job loss among Croatian people. In effect, this strategy is similar to the control-oriented strategy of non-work organization described by Kinicki and Latack (1990). Both strategies are focused on compensating for the state of deprivation that follows unemployment (see, Jahoda, 1982). However, while nonwork organization describes personal efforts oriented toward compensating in broader functions of employment and does not imply paid work activities, occasional work is a control-oriented strategy with a narrower goal and behavioral methods. This strategy implies "occasional work for money", and it is purely oriented toward decreasing experienced financial deprivation and compensating in the manifest, financial function of employment. As an active, control- and work-oriented strategy, it potentially brings the other, latent, benefits that institutional employment had in the past, but our previous study showed that this was not actually the case ( verko et al., 2008b). The two emotionoriented strategies of coping with job loss, distancing and employment devaluation, are more universal 
and common in different cultures (Hanish, 1999; Kinicki \& Latack, 1990; Leana, Feldman, \& Tan, 1998; Roger, Jarvis, \& Najarian, 1993). People generally use them to enhance their own cognitive functioning through emotional distancing from the shock they have experienced, or through downplaying bad sides of the situation they must undergo.

Which strategy a person will use as a dominant pattern of behavior in response to a stressful event depends on various factors. In general, problem-oriented coping is more likely to occur when the conditions of the stressor are appraised as possible to change through the taking of action, and emotion-oriented coping is more likely to occur when conditions are appraised as more difficult to change. Therefore, availability of personal and situational coping resources has been positively related to problem-oriented strategies and negatively related to emotion-oriented strategies (Kinicki, Prussia, \& McKee-Ryan, 2000). The study supports this general assumption: (1) Different patterns of individual characteristics were related to the tendency of using the individual strategy more or less intensively, and the strategies showed different adaptive roles in terms of their relations to measured outcomes; (2) the availability of coping resources is a strong predictor of the most adaptive problem-oriented strategy of proactive job search; (3) some measured resources were not related to emotion-oriented strategies, and some of them were in negative relations. These general findings will be discussed in more detail.

The active, problem-oriented strategy of proactive job search is more prevalent among more educated persons and those with less organizational tenure in last employment. All the examined resources, except social support, served as predictors of this strategy, and measured variables explained the greater part of the individual differences. Finally, proactive job search, not measured resources, was a significant independent predictor of reemployment six months later, in addition to age and education level (H2). The findings have proved that persons with more human capital (i.e. more educated and flexible), and those who experienced a higher level of measured resources (that is, financial deprivation, job involvement, core self-evaluation, job-search efficacy), will use job search more intensively after involuntary job loss, and this strategy is adaptive in terms of its relation to successful reemployment. The variables indicated can be observed as factors of employability among Croatian working people. They are congruent to the concept of employability, seen as a pattern of different individual characteristics, comprised in constructs of career identity, personal adaptability, and social and human capital that foster adaptive cognition, behavior, and affect within today's work environment (Fugate \& Kinicki, 2008; Fugate, Kinicki, \& Ashforth, 2004). The results supported our previous findings on predictors of job-search intensity among unemployed people in Croatia, as well as on education as a predictor of reemployment ( verko et al., 2008a). However, this study emphasized the role of this strategy as a predictor of reemployment. This was not the case in the previous study, in which employment status was measured one year later and, of crucial importance, the study was conducted on a representative sample of registered unemployed persons. One third of them had been unemployed for more than 3 years. In this sample, we surveyed people who had lost their job recently and, consequently, were on average more active.

All the measured resources describe individual strengths and capacities, except perceived financial deprivation - a resource that is different by its nature. It defines personal financial hardship after job loss. This variable indicates the financial need for employment, as well as the personal financial meaning that employment had in the past, and thus, like job involvement, it represents the motivational resource of an individual (Gowan \& Gatewood, 1997; Ullah, 1990). Interestingly, social support did not play a significant role in predicting this adaptive strategy. Although we measured perceived emotional, informational and instrumental social support (Abbey, Abramis, \& Caplan, 1985), perceived availability of this resource was related only to emotion-oriented coping and, in the follow-up, was a significant predictor of perceived work uncertainty. It seems that social capital does not speed employability among Croatian working people. The role of social support (or social capital, as it is defined in the concept of employability) remains an interesting question for future research.

The two control-oriented strategies, job search and occasional work, were interrelated (Pearson $\mathrm{r}=0.37, \mathrm{p}<0.01)$ and defined by a similar pattern of resources. However, job search is related more to adaptive coping patterns than is occasional work. Several findings support this conclusion: (1) Measured resources explained almost $32 \%$ of total variance when the criterion was job search, and less than $9 \%$ when the criterion was occasional work; (2) Core self-evaluation was not an individual 
resource for the strategy of occasional work, as it was for proactive job search; (3) Occasional work was in a positive bivariate correlation with the emotion-oriented strategy of problem distancing; (4) Finally, despite its relation to individual work capacities, the strategy of occasional work was not related to reemployment and perceived work certainty, measured in the follow-up.

Perceived financial deprivation, job-search efficacy and job involvement were positive predictors of both strategies. In addition, they were both more prevalent among people who had less organizational tenure in their last employment. Individuals that suffered from a higher level of financial deprivation, those who had higher job-search efficacy and job involvement were more likely to use both strategies more intensively. But those of higher core self-evaluation would use job-search more intensively. Gender also had a different role in predicting these strategies: while it did not moderate the intensity of proactive job search, it did so for occasional work. Men used this strategy more often, and this result is congruent with general findings on the socio-demographic characteristics of people involved in undeclared work (see, Special Eurobarometer, 2007). We can conclude that the control-oriented strategy of occasional work represents a strategy of people who experience their situation of unemployment as a state of deprivation and are motivated to work (they perceive a high financial deprivation and express a high job involvement), at the same time having capacities necessary for efficient job search, but not having other individual or situational resources to change the situation in their favor more efficiently. So this strategy represents less adaptive coping than job search. It seems that occasional work is a strategy of people who are currently defeated by the situation they end up in, and consequently find ways to survive in modern society outside institutional employment. As always in time of change, the crucial issue is that of control: a disparity between traditional claims and resources, such as social crises produce, leads to a sense of loss of control, which must be reestablished in new ways (Elder \& Caspi, 1990). Through occasional work, people try to take control over the stressful consequences of unemployment.

To the extent that a stressful situation cannot be controlled, emotion-oriented coping is used more (Lazarus \& Folkman, 1984). Consequently, older and less educated persons, as well as those of lower core self-evaluation, used distancing more intensively. Furthermore, the adaptive, problemoriented strategy of job search was in a negative relation to this strategy (Pearson $\mathrm{r}=-0.19 ; \mathrm{p}<0.01$ ). The result supports the findings on links between different strategies of coping with job loss recently claimed by Sadeh and Karniol (2012). In a study on a sample of 211 employed and unemployed Israeli citizens, they found significant positive correlations between emotion-oriented strategies and negative correlations between emotion- and adaptive problem-oriented strategies of coping with job loss. Interestingly, social support represented an individual resource only for this strategy. It seems that the "important others" are perceived in Croatian culture as a source of support for using this passive and maladaptive strategy (Roger, Jarvis, \& Najarian, 1993). Biographic variables were not significant predictors of the other emotion-oriented strategy - job devaluation. Among the measured resources, the significant predictors were core self-evaluation and job involvement. Job involvement was, assuredly, in a negative relation to the strategy of job devaluation. In contrast to distancing, job devaluation was related to a higher core self-evaluation. It can be concluded that people who experienced a higher level of core self-evaluation, accompanied with a lower level of job involvement, are more likely to use the strategy of job devaluation. At the same time, age, gender, level of education and organizational tenure in last employment do not play significant roles in that process.

Emotion-oriented coping involves cognitive and behavioral efforts to reduce the experienced distress that the situation of job loss has caused. They define individual attempts to establish control over one's own emotional reactions, and in that respect emotional-oriented strategies can be efficient in reducing distress. For that reason, we supposed that the strategies of job-loss distancing and job devaluation would be related to less work-related anxiety being measured in the follow up. But this was not the case. Contrary to the hypothesis ( $H 3$ ), the emotion-oriented strategies of problem distancing and job devaluation were not significant independent predictors of work-related anxiety six months later, in addition to the current employment status, coping resources and demographic characteristics of the individual. Only current employment status (as hypothesized in H1), biographic variables and measured resources served as significant predictors of perceived work uncertainty six months later: reemployed (i.e. successful), as well as younger, persons and those who had experienced higher core self-evaluation and more social support after job loss reported less anxiety regarding future 
employment status in the follow-up. It seems that these characteristics can be observed as resources of individual security in time of global job insecurity (see De Cuyper et al., 2008; Kidd, 2002).

\section{Study Limitations and Future Research}

There were some limitations inherent in this study that must be borne in mind while observing its results. Most important, in our view, was the convenient sample of unemployed persons, which was not totally homogeneous in length of unemployment after job loss, as well as the measures that we used. First, the measured strategies reveal empirically sound and culturally valid descriptions of the behavior of Croatian people while dealing with job loss, but the internal consistency of the scale of occasional work was rather low (.64), and this could decrease the correlations between this scale and other variables that are supposed to serve as its antecedents or outcomes. Future research is needed in defining this strategy. Second, the measured biographic variables and coping resources were not efficient in explaining the two emotion-oriented strategies, especially the strategy of job devaluation. Future research is needed to define these strategies in terms of their predictors. Third, more research is needed on the relation of these strategies to different outcomes, and their possible interactive roles in predicting future reemployment, quality of employment and different kinds of well-being. Finally, we did not collect any data on the measured strategies in terms of their persistence through time. This is especially necessary for the most adaptive strategy of proactive job search. As Lord at al. (2010), as well as van Dam and Menting (2012), recently emphasized, job search is seen as a self-regulating process, involving goal-setting, related efficacy measurement and consequent behavior self-modification, and in that respect more research is needed on the time-persistence of this strategy, as well as on its impact on the well-being of unsuccessful job seekers. Certainly, job search is not the only relevant factor. Defining the psycho-social construct of employability through searching for factors that predict successful reemployment after job loss can show us ways in which we can anticipate who will beat the crisis and who will be beaten by it. In particular, recognizing vulnerable categories of people in terms of socio-demographic, career and personal characteristics that are related to less adaptive behavior within today's work environment (e.g., van Dam \& Menting, 2012; Obschonka, Silbereisen, \& Wasilewski, 2012; Sadeh \& Karniol, 2012) is of crucial importance in the prevention of prolonged unemployment and its numerous undesirable effects.

\section{Conclusions}

The results of the current study can be summarized in several general findings: (1) Different patterns of individual characteristics were related to the tendency to use the individual strategy more or less intensively, and the strategies showed different adaptive roles in terms of their relations to future reemployment and work-related anxiety; (2) The availability of coping resources is a significant predictor of the most adaptive, problem-oriented, strategy of proactive job search; (3) Some measured resources were not related to emotion-oriented strategies, and some of them stood in negative relations; (4) Proactive job search, but not the measured resources, was a significant independent predictor of reemployment six months later, in addition to age and education level; (5) Employment status, measured after six months, was a significant independent predictor of the concurrent experience of work uncertainty - reemployed individuals experienced less anxiety regarding their future work; (6) Demographic variables and measured resources served alongside current employment status as significant predictors of work uncertainty, but strategies did not.

\section{References}

Abbey, A., Abramis, D. J., \& Caplan, R. D. (1985). The effects of different sources of social support and interpersonal conflict on emotional well-being. Basic and Applied Social Psychology, 6, 111-129.

Arambašić, L. (1994). Provjera nekih postavki Lazarusovog modela stresa i načina suočavanja sa stresom. Unpublished disertation. Zagreb: Odsjek za psihologiju Filozofskog fakulteta.

Arnold, J., and Cohen, L. (2008). The psychology of careers in industrial-organizational settings: A critical but appreciative analysis. In Hodgkinson, G. P, and Ford, J. K. (Eds) International Review of Industrial/ 
Organizational Psychology, Vol. 23 (pp. 1-44). Chichester: Wiley.

Buško, V. (2000). Procesi suočavanja i kontinuirana izloženost stresorima. Unpublished disertation. Zagreb: Odsjek za psihologiju Filozofskog fakulteta.

Calhoun, C. (1992). Social change. In E.F. Borgatta, \& M.L. Borgatta (Eds.), Encyclopedia of Sociology, Vol 4 (pp. 1807-1812). New York: Macmillan.

Creed, P. A. \& Moore, K. (2006). Social support, social undermining, and coping in underemployed and unemployed persons. Journal of Applied Social Psychology, 36, 321-339.

De Cuyper, N., Bernhard-Oettel, C., Berntson, E., De Witte, H., \& Alarco, B. (2008). Employability and employees' well-being: Mediation by job insecurity. Journal of Applied Psychology: An International Review, 57, 488-509.

De Witte, H. (1999). Job insecurity and psychological well-being: Review of the literature and exploration of some unresolved issues. European Journal of Work and Organizational Psychology, 8, 155-177.

Dekker, S. W. A. \& Schaufeli, W. B. (1995). The effects of job insecurity on psychological health and withdrawal: A longitudinal study. Australian Psychologist, 30, 57-63.

Elder, G. H. (1974). Children of the Great Depression: Social Change in Life Experiences. Chicago: University of Chicago Press.

Elder, G. H., \& Caspi, A. (1990). Studying lives in a changing society: Sociological and personological explorations. In A. I. Rabin, R. A. Zucker, R A. Emmons, and S. Frank (Eds.), Studying Persons and Lives, (pp. 201-247).New York: Springer.

Feather, N. T., \& O’Brien, , G. (1987). Looking for employment: An expectancy-valence analysis of job seeking behavior amnog young people. British Journal of Psychology, 78, 251-272.

Fugate, M., \& Kinicki, A.J. (2008). A dispositional approach to employability: Development of a measure and test of its implications for employee reactions to organizational change. Journal of Occupational and Organizational Psychology, 81,503-527.

Fugate, M., Kinicki, A. J., \& Ashforth, B. E. (2004). Employability: A psycho-social construct, its dimensions, and applications. Journal of Vocational Behavior, 65, 14-38.

Galić, Z., Maslić Seršić, D., \& Šverko, B. (2006). Financijske prilike i zdravlje nezaposlenih u Hrvatskoj: Vodi li financijska deprivacija do lo ijeg zdravlja? (Financial circumstances and health of unemployed persons in Croatia: Does financial deprivation lead to poorer health?) Revija za socijalnu politiku, 13, 257-269.

Gowan, M. A., \& Gatewood, R. D. (1997). A model of response to the stress of involuntary job loss. Human Resource Management Review, 7, 277-297.

Hanisch, K. A. (1999). Job loss and unemployment research from 1994 to 1998: A review and recommendations for research and intervention. Journal of Vocational Behavior, 55, 188-220.

Hrvatski zavod za zapo ljavanje(HZZ): http://www.hzz.hr/default.aspx?id=4114 (Lasti visit: December 15, 2011)

Jahoda, M. (1982). Employment and Unemployment: A Social Psychological Analysis. New York: Cambridge University Press.

Judge, T. A., Erez, A., Bono, J. E., \& Thoresen, C. J. (2003). The core self-evaluations scale: Development of a measure. Personnel Psychology, 56, 303-331.

Kalleberg, A. L. (2009). Precarious work, insecure workers: Employment relations in transition. American Sociological Review 74,1-22.

Kanfer, R., Wanberg, C., \& Kantrowitz, T. M. (2001). Job search and employment: A personality-motivational analysis and meta-analytic review. Journal of Applied Psychology, 86, 837- 855.

Kidd, J. M. (2002). Careers and career management. In P. B. Warr (ed.) Psychology at Work. Fifth edition. Harmondsworth: Penguin.

Kinicki, A. J. \& Latack, J. C. (1990). Explication of the construct of coping with involuntary job loss. Journal of Vocational Behavior, 36, 339-360.

Kinicki, A. J., Prussia, R. E., \& McKee-Ryan, F. M. (2000). A panel study of coping with involuntary job loss. Academy of Management Journal,43, 90-100.

Lai, J. C. L. \& Chan, R. K. H. (2002). The effects of job-search motives and coping on psychological health 
and re-employment: A study of unemployed Hong Kong Chinese. International Journal of Human Resource Management, 13, 465-483.

Latack, J. C. (1986). Coping with job stress: Measure and future direction for scale development. Journal of Applied Psychology, 71, 377-385.

Lazarus, R. S. \& Folkman, S. (1984). Stress, Appraisal and Coping. New York: Springer.

Leana, C. R., \& Feldman, D. C. (1990). Individual responses to job loss: Empirical findings from two field studies. Human Relations, 43, 1155-1181.

Leana, C. R., \& Feldman, D. C. (1992). Coping With Job Loss: How Individuals, Organizations, and Communities Respond to Layoffs. New York: Lexington.

Leana, C. R., \& Feldman, D. C. (1995). Finding new jobs after a plant closing: Antecedents and outcomes of the occurrence and quality of reemployment. Human Relations, 48, 1381-1401.

Leana, C. R., Feldman, D. C., \& Tan, G. Y. (1998). Research predictors of coping behavior after a layoff. Journal of Organizational Behavior, 19, 85-97.

Lord, R. G., Diefendorff, J. M., Schmidt, A. M., \& Hall, R. J. (2010). Self-regulation at work. In S. T. Fiske (Ed.). Annual Review of Psychology, 61, 543-568. Chippewa Falls, WI: Annual Reviews.

Mantler, J., Matejicek, A., Matheson, K., \& Anisman, H. (2005). Coping with employment uncertainty: A comparison of employed and unemployed workers. Journal of Occupational Health Psychology, 10, 200-209.

Maslić Seršić, D., Šavor, M. (2011). Konstrukcija skale suočavanja s gubitkom posla (Construction of coping with job loss scale). Društvena istraživanja. 20, 495-515.

McKee-Ryan, F. M., Song, Z., Wanberg, C. R., \& Kinicki, A. (2005). Psychological and physical well-being during unemployment: A meta-analytic study. Journal of Applied Psychology, 90, 53-76.

Obschonka, M., Silbereisen, R. K., \& Wasilewskiet, J. (2012). Constellations of new demands concerning careers and jobs: Results from a two-country study on social and economic change. Journal of Vocational Behavior,80, 211-223.

Paul, K. I., \& Moser, K. (2009). Unemployment impairs mental health: Meta-analysis. Journal of Vocational Behavior, 74, 264-282.

Pedersen, S. (2003), The shadow economy in Germany, Great Britain and Scandinavia. A measurement based on questionnaire surveys. Copenhagen: The Rockwool Foundation Research Unit.

Prussia, G. E., Fugate, M., \& Kinicki, A. J. (2001). Explication of the coping goal construct: Implications for coping and reemployment. Journal of Applied Psychology, 86, 1179-1190.

Renoy, P., Ivarsson, S., van der Wusten-Gritsai, O., \& Meijer, E. (2004). Undeclared work in an enlarged Union. An analysis of undeclared work: An in-depth study of specific items. Report. European Commission. Directorate-General for Employment and Social Affairs. Unit EMPL/A/1. May, 2004, p. 242.

Rife, J., \& Kilty, K. (1990). Job search discouragement and the older worker: Implications for social work practice. Journal of Applied Social Sciences, 14, 71-94.

Roger, D., Jarvis, G., \& Najarian, B. (1993). Detachment and coping: The construction and validation of a new scale for measuring coping strategies. Personality and Individual Differences, 15, 619-626.

Sadeh, N., \& Karniol, R. (2012). The sense of self-continuity as a resource in adaptive coping with job loss. Journal of Vocational Behavior, 80, 93-99.

Savickas, M. L. (2005) The theory and practice of career construction. In S.D. Brown, \& R.W. Lent (Eds) Career Development and Counseling: Putting Theory and Research to Work (pp. 42-69). New Jersey, USA: John Wiley \& Sons Inc.

Silbereisen, R. K., Pinquart, M., \& Tomasik, M. J. (2010). Demands of social change and psychosocial adjustment: Results from the Jena study. In R. K. Silbereisen \& X. Chen (Eds.), Social change and human development: Concepts and results (pp. 125-147). London: Sage Publications.

Special Eurobarometer (2007). Undeclared Work in the European Union. Report. October, 2007. European Comission.

Sverke, M., \& Hellgren, J. (2002). The nature of job insecurity: Understanding employment uncertainty on the brink of a new millenium. Applied Psychology: An International Review, 51, 23-52.

Song, Z., Wanberg, C., Niu, X., \& Yizhong, X. (2006). Action-state orientation and the theory of planned 
behavior: A study of job search in China. Journal of Vocational Behavior, 68, 490-503.

Šverko, B., Galešić, M., Maslić Seršić, D. (2004.) Aktivnosti i financijsko stanje nezaposlenih u Hrvatskoj. Ima li osnova za tezu o socijalnoj isključenosti dugotrajno nezaposlenih osoba? (Activities and financial situation of unemployed persons in Croatia. Is there an indication of social exclusion of the long-term unemployed persons?) Revija za socijalnu politiku, 11, 283-298.

Šverko, B., Galić, Z., Maslić Seršić, D., Galešić, M. (2008a). Unemployed people in search of a job: Reconsidering the role of search behavior. Journal of Vocational Behavior, 72, 415-428.

Šverko, B., Galić, Z., Maslić Seršić, D., \& Galešić, M. (2008b). Working int he hidden economy: Associations with the latent benefits and psychological health. European Journal of Work and Organizational Psychology, 72, 415-428.

Ullah, P. (1990). The association between income, financial strain, and psychological well-being among unemployed youth. Journal of Occupational Psychology, 63, 317-330.

van Dam, K., \& Menting, L. (2012). The role of approach and avoidance motives for unemployed job search behavior. Journal of Vocational Behavior 80, 108-117.

Vansteenkiste, M., Lens, W., De Witte, H., \& Deci, E. L. (2004). The 'why' and 'why not' of job-search behaviour: Their relation to searching, unemployment experience, and well-being. European Journal of Social Psychology, 34, 345-363.

Vinokur, A., \& Caplan, R. D. (1987). Attitudes and social support: Determinants of job seeking behavior and well-being among the unemployed. Journal of Applied and Social Psychology, 17, 1007-1024.

Vukelić, A, (2003). Anomija pojedinih socijalnih grupa suvremenog hrvatskog društva. Unpublished disertation. Zagreb: Odsjek za sociologiju Filozofskog fakulteta.

Wanberg, C. R., Glomb, T. M., Song, Z., \& Sorenson, S. (2005). Job-search persistance during unemployment: A 10 wave longitudinal Study. Journal of Applied Psychology, 90, 411-430.

Wanberg, C. R., Kanfer, R. \& Rotundo, M. (1999). Unemployed individuals: Motives, job-search competencies, and job-search constraints as predictors of job seeking and reemployment. Journal of Applied Psychology, 84, 897-910.

Wanberg, C. R., Watt, J. D., \& Rumsey, D. J. (1996). Individuals without jobs: An empirical study of jobseeking behavior and reemployment. Journal of Applied Psychology, 81, 76-87.

Warr, P., Cook, J. \& Wall, T. (1979). Scales for the measurement of some work attitudes and aspects of psychological well-being. Journal of Occupational Psychology, 52, 2-12.

Zenger, M., Brähler, E., Berth, H., \& Stöbel-Richter, Y. (2011). Unemployment during working life and mental health of retirees: Results of a representative survey. Aging \& Mental Health, 15, 178-185.

Advised by Vincentas Lamanauskas, University of Siauliai, Lithuania

Received: January 12, 2012

Accepted: March 23, 2012

\begin{tabular}{cl}
\hline Darja Maslić Seršić & $\begin{array}{l}\text { Ph.D., Associate Professor, University of Zagreb, Ivana Lucica 3, } 10000 \text { Zagreb, Croatia. } \\
\text { E-mail: darja.maslic@ffzg.h. } \\
\text { Website: http://psy.psych.colostate.edu/psylist/detail.asp?Num=322 }\end{array}$ \\
\hline Majda Šavor & $\begin{array}{l}\text { M.A., Croatian Employment Service, Domobranska 19, } 47000 \text { Karlovac, Croatia. } \\
\text { E-mail: msavor@inet.hr }\end{array}$ \\
\hline
\end{tabular}

